\title{
Beyond transgression: Mountain biking, young people and managing green spaces Katherine King $^{\mathrm{a}}$ \& Andrew Church ${ }^{\mathrm{b}}$ \\ ${ }^{a}$ Bournemouth University \\ ${ }^{b}$ University of Brighton
}

\begin{abstract}
:
The importance of regular participation in physical activity in youth has seen attention turn to the role of lifestyle sports. Existing research on lifestyle sports lacks consideration of young people's use of green spaces and the approaches of managers to conflicts in these spaces. Young people's experiences of leisure are closely tied to those who oversee their use of leisure spaces and this paper is a rare example of research that draws upon qualitative methods from 40 mountain biking participants and 9 managers to explore both perspectives. Findings reveal young people seek opportunities for autonomy in green spaces through mountain biking but contest normative management practices. Managers recognised the benefits of engaging young people in mountain biking and discussed experimenting with various strategies to accommodate their practices. The paper therefore discusses the importance of moving beyond constructions of young people's participation in lifestyle sports as transgressive and troublesome.
\end{abstract}

Keywords: Green space, youth, lifestyle sports, management, conflict 
The choices young people make during their leisure time are becoming widely recognised as crucial to their physical, psychological and social development. Participation in physically active leisure is recognised as key to improving quality of life (Sato, Jordan \& Funk, 2014). For example, the importance of regular participation in physical activity in youth for preventing non-communicable diseases and supporting psychological well being has been recognised on a global scale (cf. WHO, 2004). Participation in sport is considered important for the future development of healthy lifestyles (Thompson, Rehman \& Humbert, 2005) and can play a role in addressing youth anti-social behaviour and reducing youth crime (Nichols, 2007; DH, 2010).

In England, as in many other countries (e.g. HHS, 2008; WHO, 2007; 2010), the benefits of being physically active through sport has resulted in many national policies focusing on increasing sport participation by young people between the ages of 16 and 25 years (DCMS, 2012; DH, 2010). In order to engage hard to reach young people and those currently disengaged from conventional team or school based sports, delivery of activities now includes a more wide ranging profile of sports and organisations, including more informal forms of participation such as those offered by lifestyle sports (cf. Rowe, 2012; Tomlinson, Ravenscroft, Wheaton \& Gilchrist, 2005). Lifestyle sports are defined as activities that enable participants to express themselves as individuals through recognizable styles, attitudes and other cultural preferences such as music, art and fashion alongside the sport itself (Wheaton, 2010). Club based sport has been recognised as exclusive and out of touch with modern forms of consumption (Goretzki, Esser \& Claydon, 2008) and attention has turned to creating a socially, psychologically and physically beneficial sporting habit that 
can be embedded alongside other choices young people make about the ways in which they live their lives (DCMS, 2012; Sport England, 2014).

In addition to the type of sports young people choose to undertake to be physically active, the spaces in which they spend their leisure time have been identified as a further means to improve young people's wellbeing. Green spaces are considered to be beneficial to the physical and mental health and social development of young people (Cooper, 2005; Gardsjord, Tveit \& Nordh 2014; Gill, 2014; Milligan \& Bingley, 2007). Of particular interest is the potential role of performing sporting activities in rural and green spaces, referred to as 'nature sports' (Melo \& Gomes, 2017).

The recognition of the potential benefits of lifestyle sport participation and use of green space by young people amongst policymakers and leisure space managers has been accompanied, however, by an emerging academic literature that has simultaneously highlighted some of the key social problems that have arisen when public spaces are used by young people for lifestyle sports. This body of research reveals how young people can often experience the public spaces they wish to access for lifestyle sports as a battleground between themselves, managers, landowners and other users as they pursue activities which are perceived as risky or problematic, even when the managers of these spaces are encouraging their use (cf. Beal \& Weidman, 2003; Borden, 2001; Gilchrist \& Wheaton, 2011; Németh, 2006; King \& Church, 2017).

An extensive body of research has developed seeking to understand user conflicts in outdoor recreation and how these conflicts can be managed (see Watson, Cordell, Manning \& Martin, 2016 for summary). Previous research has tended to understand conflict as a form of 
competition between user groups often based on goal interference. Ewert, Desier and Voight (1999, p. 337) defined conflict linked to recreation as being 'when one person, or group of people, experience or perceive an interference of goals or the likelihood of incompatible goals'. A related conceptual model of recreational conflict is the social values approach, which views conflict as stemming from differences in norms, beliefs and values (Vaske, Donnelly, Wittmann \& Laidlaw 1995). Education is often considered an appropriate policy response when conflict is values based whereas zoning can be used to deal with goal interference (Watson et al. 2016). The social values and goal interference theorisations both understand conflict from a social or psychological perspective based on the nature of intergroup or interpersonal relationships. Church, Gilchrist and Ravenscroft (2007) have argued, however, that these conceptual approaches tend to pay little attention to the context in which conflicts take place and the related role of resource settings, power relations or property rights in influencing the types of conflict that occur.

The research questions framing this study are what are the key issues in the use of space and the management of tensions and conflicts associated with young people's involvement in lifestyle sport and how are these experienced by both young people and green space managers? The paper provides a distinct contribution to existing debates as it not only focuses on the sport of mountain biking, which is recognised as under-researched within the field of youth lifestyle sports compared to activities such as surfing and skateboarding (Wheaton, 2010), but also is a rare example of where the findings presented are based on primary data derived from both youth participants and the managers of green spaces. 
Research in a variety of disciplines has revealed some important and distinct relations between youth lifestyle sports and the spaces in which they are situated. Youth is considered an ambiguous state: between, but in tension with the realms of adulthood and childhood. Such an ideological state creates uncertainty for young people, who are challenged to become active members of society but instead occupy a liminal state (Valentine, 2004; Wood, 2012). This is exemplified most notably through the interaction between young people and the everyday spaces in which they live out their leisure lifestyles in which they are now encouraged to participate but often on terms defined by adults.

The shaping of youth leisure activities is a spatially situated process for young people and the freedom to assert ownership is central to the youth leisure experience (Shildrick, Blackman \& Macdonald, 2009). Young people draw a sense of ownership from their collective occupation of leisure spaces (Robinson, 2009) yet a lack of access to backstage spaces such as local streets and neighbourhoods where they are free to enact their lifestyles has seen youth groups accused of transgressing what is acceptable in public leisure spaces and creating youth territories (Brown, 2013; Matthews, Limb \& Taylor, 2000; Owens, 2002). Gidlow and Ellis (2011) highlight how urban green spaces are valued by young people as a point of congregation but this is often congruent with adult concerns about anti-social behaviour. As a result young people report feeling ownership over green spaces they visit but often this is accompanied by other feelings of persecution for what they perceive as unjust blame for tensions and conflicts linked to vandalism and misuse (Gidlow \& Ellis, 2011).

Young people participating in lifestyle sports encounter similar tensions and conflicts. The youth based cultures associated with lifestyle sports have been found to be characterised 
by a departure from the values of mainstream sport such as competition, rules or team participation. Instead, they privilege individuality, informality, non-conformity and freedom from rules, including often the rules imposed by the managers of public space (cf. Beal \& Weidman, 2003; Gilchrist \& Wheaton, 2011; Rinehart \& Grenfall, 2002; Wheaton, 2010). Sports such as skateboarding, parkour and BMX are popular with young people, yet, the alternative and unstructured nature of participation activities and their associated spaces can mark them as transgressive, deviant, and antagonistic to the urban environment (Beal \& Weidman, 2003; Borden, 2001; Gilchrist \& Wheaton, 2011; Németh, 2006; Owens, 2001). It is argued therefore that youth participation in these sports is often the subject of passive marginalisation by urban planners who lessen conflict and tensions by restricting these activities in certain civic locations, or diverting them to state funded, indoor, or corporate sites where behaviour and activities can be packaged, observed and controlled (Taylor \& Khan, 2011; Owens, 2001; Van Bottenburg \& Salome 2010; Woolley, Hazelwood \& Simkins, 2011).

Despite these tensions between youth lifestyle sports and urban space management previous research has revealed positive interconnections between lifestyle sport participants and the spaces utilised. For example, management in relation to parkour spaces that seek to address the lifestyle dimension of these sports has been found to create a sense of ownership of the spaces amongst young people involved (Gilchrist \& Wheaton, 2011). This reflects the general argument in outdoor recreation that it is important to examine the experiential variables of outdoor activities in order to inform and improve management strategies (Hallo, Manning, \& Stokowski, 2009). Thus, it is important to explore, as the empirical research in this paper does, how the management of spaces for youth lifestyle sports can increase participation and provide opportunities for the aspects of lifestyle sports that young people 
seek and find physically, mentally and socially beneficial whilst managing tensions, transgression or anti-social behaviours.

To date, youth lifestyle sport writings which explore the interconnection between participants and their leisure spaces have been almost entirely urban centred. There is little written about young people's use of green spaces for lifestyle sports, including spaces in urban parks away from formally designated areas, woodlands and the wider natural environment. There has been extensive research on the opportunities for young people to experience risk through formally managed adventure in green spaces (e.g., Cater, 2006; Hinds, 2011; Lekies, Yost \& Rode, 2015) and a small body of work also identifies a preference by young people for using certain green spaces for informal leisure activities (c.f. Bell, Ward Thompson \& Travlou, 2003; Lloyd, Burden \& Kiewa, 2008; Milligan \& Bingley, 2007). Nevertheless, research that considers the management issues of young people's use of green spaces tends to be from a youth perspective and there continues to be insufficient understanding of the consequent response by managers and landowners to the activities of young people who choose to visit urban, peri-urban and rural green spaces to take part in lifestyle sports (King \& Church, 2017). These knowledge gaps may limit the effectiveness of policies to increase lifestyle sport participation.

\section{Mountain biking and the spaces of lifestyle sports}

Mountain biking is one example of a lifestyle sport which presents an opportunity to increase young people's engagement with physical activity and green spaces. It is also a sport which is increasing in popularity internationally (Hardiman \& Burgin, 2013), and within the 
UK has seen an increase in participation post-Olympics (Sport England, 2016). It is estimated to account for $9 \%$ of all outdoor recreational activities in England (Sport England \& Outdoor Industries Association, 2015). Mountain biking, however, is not a homogenous activity with disciplines continually evolving and new styles emerging.

Mountain biking can provide valuable insights into the relationships between youth lifestyle sport and space because it is a highly mobile activity yet these spaces are also typically environments which are subject to competing demands from different recreational groups. Unlike other lifestyle sports which may be dependent upon specific landscapes or fixed facilities, provision for mountain biking in the UK is formed largely of formal pay to ride or club owned mountain bike parks for dirtjump, downhill and freeride disciplines, or trail centres or open access state managed land for cross country riding. In addition, mountain biking is practised informally in rural green spaces, peri-urban or urban environments such as in freely accessible parks and woodlands, street spaces or on privately owned land accessed with or without landowner permission. It is in these informal environments that participants are able to create their own jumps, trails and apparatus.

The majority of research into mountain biking has been conducted within a North American context (Leberman \& Mason, 2000, Zajc \& Berzelak, 2016) although notably, research also originates from Australia and New Zealand. Within this literature, mountain biking has often been described in terms of 'controversy and discord' (Hollenhorst, Schuett, Olson \& Chavez, 1995, p. 41) and has received substantial scrutiny over its negative impacts. Mountain bikers are often held responsible for ecological degradation of sensitive rural environments (c.f. Quinn \& Chernoff, 2010; White, Troy Waskey, Brodehl \& Foti, 2006) and for causing conflict with other recreational user groups (c.f. Cessford, 2003; Carothers, Vaske 
\& Donnelly, 2001). An important challenge for mountain biking management, therefore, involves the conflicts between mountain bikers and other users in green spaces (Zajc \& Berzelak, 2016) and balancing the preferences of users against management concerns to reduce environmental impacts, particularly through the creation and use of unofficial trails (D’Antonio, Monz, Larson, \& Rohman, 2016).

Mountain bikers of all ages have been positioned as non-traditional recreationists whose activities require complex management strategies (Brown, 2016). The negative characterisation of mountain biking can, however, be problematic if it results in a limited understanding of the social benefits young people gain from the activity and also the undervaluing of the successes of managers in influencing mountain biking behaviours to ensure positive experiences for youth participants whilst addressing the demands of other users and owners of the leisure space. Zajc and Berzelak (2016) stress that mountain bikers are not a homogeneous group of outdoor recreationists. Rather, they differ in skill levels, motivation, equipment, riding styles, as well as other characteristics which will affect the mountain biking experience and consequently the management approach required. More generally it is argued that understanding the values mountain bikers hold and the social benefits they gain from their sport are important issues for managers of green spaces to take account of in devising initiatives (Pickering \& Rossi, 2016).

This paper, therefore, presents insights based on primary research into both participant and management experiences of mountain biking that addresses the general lack of research on mountain biking management, especially in European locations. Specifically, it focuses on youth mountain biking in a range of peri-urban and rural green spaces in the South of England, a particularly densely populated region, to consider some of the critical debates surrounding youth lifestyle sports, the tension and conflicts that arise around these 
sports and the resulting implications for management of green spaces for encouraging physical activity.

\section{Methodology}

This article draws upon two sets of data collected as part of a sequential qualitative study set in the South of England to explore youth lifestyle sports activities and the resulting implications for managers of green spaces addressing what Hallo et al. (2009) identify as underrepresentation of qualitative methodologies in assessing outdoor recreational experiences.

In the sequential research design, the results of the first phase of the study inform the subsequent phase with the analysis building upon the findings of the first phase (Mason, 2002). A two phased approach embeds reflective practice within research, positioning the research process as cyclical and reflexive through which the researcher can learn, reflect and respond. Unlike a purely management focused approach, the rationale for this approach was to share the feedback from young people who are traditionally marginalised from mainstream management of green spaces with the managers of those environments. The approach sought to obtain new perspectives from leisure managers on key themes which were derived from analysis of the first research phase with users themselves. Whilst a sequential approach is most commonly adopted for mixed methods research (cf. Creswell, 2003; Mason, Ausutyn \& Seakhoa King, 2010), in this study qualitative methods were administered in both phases under an interpretative framework which offered credibility, dependability and transferability of the data through the interaction between the two phases (Lincoln \& Guba, 1985). In the first phase, qualitative research was adopted to provide an in-depth account of the embodied and performative characteristics of participation by young people not readily captured by structured approaches (Monrad, 2013). Similarly, the second phase of the study invited 
managers to reflect on their own subjectivities in their approaches to management of youth mountain biking activities in green spaces.

The first data set was drawn from ethnographic research with 40 participants aged between 13 and 25 years who participated in mountain biking across a range of urban, periurban and rural locations. The study was sensitive to the ethics of working with young people, adopting a youth centred approach to the research that empowered young people to voice their own experiences. The research design adhered to a UK university research ethics code of practice and sought written consent and parental permission from those participants under 16 years of age. The purpose of this part of the study was to investigate the role of green spaces for youth lifestyle sport participation. The methodology sought to be inclusive of a range of youth experiences and following Roberts (2006), acknowledges the prolonging of youth to include those up to 25 years of age. Age, however, is accepted as a fluid category and it was important to recognise the variation in experiences that occurs within a wide age range. Respondents were recruited through their participation at a large publically managed destination which offered facilities for freeride, dirtjump and cross-country mountain biking and was well used by young people. It must be noted, however, that mountain biking participants rarely limit their participation to one location. Instead they concurrently access multiple sites according to skill level, accessibility, social factors, cost, etc and results therefore reflect this multi-site perspective. Purposive theoretical sampling was employed to select individuals according to their expected contribution of insights for the development of theory (Flick, 2005). In this case all participants were required to have participated in mountain biking at the designated study site in the previous six months. Recruitment of the participants was achieved primarily through the ethnographic presence of the researcher at the designated study site (see table 1) and performed secondarily through snowballing as 
there was no accessible sampling frame for the population (Bryman, 2015). The sample included members of formally recognised mountain biking clubs $(n=13)$ and those that participated without any club affiliation $(n=27)$. Respondents differentiated themselves according to their cycle discipline and included cross-country, dirtjump, downhill and freeride mountain bikers, BMX riders and some young people who participated across these disciplines (see table 1). This typifies the heterogeneity of mountain bikers in terms of skills and activities (Zajc and Berzelak, 2016). Approximately $90 \%$ of respondents were male, replicating similar gender profiles of participation in mountain biking in the UK (Ruff \& Mellors, 1993). 
Table 1: Phase 1 Research Methods

\begin{tabular}{|c|c|}
\hline Method of Participant Recruitment & $\begin{array}{r}\text { No of } \\
\text { participants }\end{array}$ \\
\hline Online Advertisements & 6 \\
\hline On Site Advertisements & 3 \\
\hline Cycle Club Meets & 12 \\
\hline Leisure Cycling Encounters & 10 \\
\hline Snowballing (Existing Contacts) & 9 \\
\hline Total & 40 \\
\hline \multicolumn{2}{|l|}{ Participant Observation } \\
\hline Accompanied Mobile Methods & 10 \\
\hline Unaccompanied Mobile Methods & 5 \\
\hline $\begin{array}{l}\text { Accompanied Participant } \\
\text { Observation in Cycle Space }\end{array}$ & 25 \\
\hline Total & 40 \\
\hline \multicolumn{2}{|l|}{ Semi Structured Interviews } \\
\hline Group & 19 \\
\hline Individual & 21 \\
\hline Total & 40 \\
\hline \multicolumn{2}{|l|}{ Participant Disciplines } \\
\hline BMX Dirt Jump & 2 \\
\hline MTB Dirt Jump & 5 \\
\hline $\begin{array}{l}\text { Dirt Jump / Downhill / Freeride } \\
\text { (DDF) }\end{array}$ & 12 \\
\hline Cross Country & 14 \\
\hline $\begin{array}{l}\text { Cross Country / Downhill / } \\
\text { Freeride / DDF }\end{array}$ & 7 \\
\hline Total & 40 \\
\hline
\end{tabular}


In line with youth centred approaches to research (Holland, Renold, Ross \& Hillman, 2010) all participants took part in semi-structured interviews individually or in groups according to their own preference, and participants also chose the setting for interviews which was usually within the leisure space itself. Interviews sought to explore the lifestyle and identity formation of young people who visit countryside spaces for leisure. In addition, each participant took part in participant observation activities such as a mobile interview or observation where respondents participated in the sport whilst documenting their own reflections on their practices either with or without the researcher present. All data recordings were transcribed alongside fieldnotes taken by the researcher as part of the participant observations and were subjected to a process of thematic analysis whereby themes and subthemes were developed, reviewed and defined. The analysis process revealed four themes surrounding young people's use of green spaces for mountain biking which related to the management of green spaces and reflect debates in the literature discussed earlier in the paper. The first theme identified was the importance of developing a sense of ownership and belonging for green spaces. The second was liminal and transgressive activities that occur as part of young peoples' mountain biking in green spaces. The third theme relates to conflict which occurred between young people and other user groups in green spaces and the final theme explored young peoples' experiences of formal management processes. These four themes were then explored from a leisure management perspective in the second phase of the sequential study.

The second phase of research was subsequently conducted with actors involved in managing green spaces for mountain biking in the South of England during 2013. Following the themes identified in the first phase, interviews focused on interactions between managers 
and local user communities, specifically addressing the development of ownership and belonging amongst users, the management of user conflict and transgressive activities, and engaging young people in the management of green spaces. Semi-structured interviews were conducted face to face or via telephone with nine participants representing a range of urban, peri-urban and rural locations and a variety of authority roles such as site managers, rangers, club chairpersons and trail builders (see table 2). Informants were based at publically funded leisure sites in multiple destinations across the south of England and all held at least one formally recognised role such as site manager, club chairperson, club committee member, or coach in either a voluntary or employed capacity, with many acting in several different roles. All were male, had previous mountain biking experience and were usually long standing participants in the sport. All were over 25 years of age. Consequently, the associated lifestyles and cultures and their user experiences often shaped their actions as 'user managers' of clubs, spaces and facilities (cf. King \& Church, 2017). 
Table 2: Phase 2 Research Participant Details

\begin{tabular}{|c|l|l|l|}
\hline Participant & \multicolumn{1}{|c|}{ Role } & \multicolumn{1}{|c|}{$\begin{array}{c}\text { Status } \\
\text { (Employed / } \\
\text { Volunteer }\end{array}$} & \\
\hline $\mathbf{1}$ & $\begin{array}{l}\text { Site Manager } \\
\text { Club volunteer co-ordinator }\end{array}$ & $\begin{array}{l}\text { Employed } \\
\text { Volunteer }\end{array}$ & Single Site \\
\hline $\mathbf{2}$ & Multi site Manager & Employed & Multiple Sites \\
\hline $\mathbf{3}$ & $\begin{array}{l}\text { Club Secretary } \\
\text { Club Safety Officer }\end{array}$ & $\begin{array}{l}\text { Volunteer } \\
\text { Volunteer }\end{array}$ & Single Site \\
\hline $\mathbf{4}$ & Club Volunteer & Volunteer & Single Site \\
\hline $\mathbf{5}$ & Site Ranger & Employed & Multiple Sites \\
\hline $\mathbf{6}$ & $\begin{array}{l}\text { Club volunteer } \\
\text { Trail builder } \\
\text { Sports Development Officer }\end{array}$ & $\begin{array}{l}\text { Voluntary } \\
\text { Employed }\end{array}$ & Multiple Sites \\
\hline $\mathbf{7}$ & Club Youth Coach & Volunteer & Single Site \\
\hline $\mathbf{8}$ & Club Chair person & Volunteer & Single Site \\
\hline $\mathbf{9}$ & Multi site Manager & Employed & Multiple Sites \\
\hline
\end{tabular}

This second phase employed purposive theoretical sampling and participants were recruited through snowballing which enabled flexibility and dynamism in the relationship between the research aims, the data collected in the first phase and debates within the literature identified earlier in the paper around youth lifestyle sports, spaces and the conflicts and tensions that arise. Interviews were transcribed and subjected to thematic analysis using the coding framework developed as part of the first research phase. Respondents gave written consent for the recording of data and all participant names, roles and locations have been anonymised to protect participant confidentiality. 


\section{Findings}

\section{Youth in green spaces: conflict and transgression}

Results from the first phase of the research indicated that youth mountain bikers use an assemblage of cycling spaces to perform their sport incorporating public, privately managed and informal spaces which were accessed both with and without authorisation from landowners, sometimes resulting in conflicts linked to property rights. Participants chose sites for mountain biking based upon resource characteristics such as accessibility, property ownership, trail quality, cost, atmosphere and social scene. Most locations were constructed by participants as green or peri-urban, with the exception of those who described using skate parks or took part in street riding near to their home environments in addition to riding in green spaces.

Young people expressed a positive attitude towards green spaces as a leisure resource that supports the lifestyle and ethos of their sport but were also clear that this did not mean they adopted traditional attitudes to the natural environment they associated with other users such as walkers or nature enthusiasts (King \& Church, 2013). Wooded areas were deemed the preferred environment for mountain biking affording the appropriate terrain, topography and shelter, yet the separation of these environments from everyday urban spaces was also an important feature, as demonstrated in the following examples:

'We say it's a bit of an escape really, like you can come here and relax' (Participant 20: Age 16) 
'There's no-one telling you what to do, there's no-one for miles around. It's much more freer sort of thing...that's part of the reason we're in the woods though is to get away from other people' (Participant 14: Age 18)

In managed green spaces such as designated bike parks or trails, where sites were mixed use or were easily accessible for wider public use, most participants valued the facilities this provided but two participants described how they sought to avoid encounters with other users or payment for entry instead preferring to carry out their activities unobserved.

'We've got no reason to go to the visitor centre, we come in down a back lane, it takes about ten minutes to get here cos another person we know from biking he told us about that back lane way' (Participant 19: Age 16)

'I start early enough so that we don't have to pay' (Participant 12: Age 16)

Despite the positive qualities of green spaces, most participants in this study reported restrictions in their ability to access the full range of spaces their local environment offered for performing their sport. Young people's use of green spaces can be perceived by others as both anti-social and spatially inappropriate. This is particularly apparent for young people who participate in non-traditional sports such as mountain biking where the nature of mobility and risk involved in these may conflict with the tranquility of these spaces (Ruff \& Mellors, 1993; Dougill \& Stroh, 2001). Consequently, approximately two thirds of respondents described a threatened relationship in their use of them: 
'There's quite a few jump spots round here, but when people say oh [the] scenery and countryside is so nice, but you find out at the end of the day it's all landowners who'd probably shoot you if you rode' (Participant 24: Age 18)

'We are always getting moaned at, it doesn't matter where we go someone has a problem with us for some reason' (Participant 14: Age 18)

Managers of green spaces also recognised the difficulties faced by young people in accessing green spaces for mountain biking. Three of these respondents described fragile relationships with neighbouring landowners and the difficulties they faced in negotiating between different stakeholder and user groups, particularly when concerning provision that offers the challenge and excitement that young people often seek.

'Local people, they are mainly retired in their sixties and middle class people and they are more about preserving the park for their own benefit. So they are more concerned about are the flowers going to stay as opposed to are we going to build something that is going to get young people to use the park' (Manager 1)

'Well I mean we have to be quite careful with our neighbours cos they are very wealthy people and very influential so we have to like bow our heads when they are around and keep the site ultra tidy and keep the music down and we have to make sure the road is kept swept and kept clean and we sort of we have to inform them if we have a race going on and we try and keep them onside the best we can. You know you have mountain bikers one side of the wood and other side is multimillionaires in their houses' (Manager 3) 
The fragility of access to green spaces saw young people in this study form strong attachments to those sites which they were able to use unhindered. At managed mountain biking destinations where paths were clearly marked, several participants recounted experiences of defending what they considered to be their space and expressed frustration when the boundaries were breached by other users such as in the example below:

'There's a forest track and I think it's just for bikes, like it's not for horses, it's not a bridleway, and everything in that area is especially for mountain bikers so we're like the top dog and there's people doing jumps and everyone's watching and a horse rider came up and she had a young girl on a smaller pony with her and we were going up and down and she goes and shouts at me, saying keep the noise down, and I was just like well you're not supposed to be here anyway it's not a bridleway' (Participant 40: Age 24)

Participants expressed feelings of frustration when they failed to exercise power and ownership in managed spaces. In addition to cycling itself, they sought out opportunities to design, shape and build within the terrain and saw this as an integral part of the sport which facilitated the progression and development of their skills. Six of the managers described opportunities for maintaining trails which were available to young people through organised 'dig days'. However, these were often co-ordinated through local cycle clubs or park management and involvement with formal structures was identified as problematic. 
'Keen cyclists even the road cyclists seem to have a passion for cycle clubs. Mountain bikers seem to be completely the opposite and they almost view a club as almost an infringement on their freedom' (Manager 9)

'As a group there are always some who don't want to conform and don't want it formal they just want to turn up and ride and there will always be ones who can't engage within the same way and you can't get that sort of formal structure going' (Manager 2)

In addition, these activities rarely provided the opportunity to design or build new apparatus and therefore 28 out of 40 respondents identified either accessing informal spaces called secret spots or taking part in wild build ${ }^{1}$ in locations that were sheltered from other users or managers and therefore less likely to be restricted.

'If it's a secret place then it's loads better cos like places that are open to the public often have like safety and stuff but these ones can make it as rad [radical] as they like' (Participant 19: Age 16)

'Near where I live, there's woods down the bottom and me and my mates build there all the time like pretty much most days, we've got these woods that no one has heard about' (Participant 16: Age 17)

Almost every manager in this study described examples of mountain bikers accessing areas and property beyond those which were sanctioned, for example, by straying from

\footnotetext{
${ }^{1}$ Wild build refers to unauthorized trail building in secret locations in green spaces.
} 
maintained pathways or creating new routes within existing mountain biking sites without the permission of management staff.

'We still get people that want desire lines they are called and we block them off with dead hedging and piles of branches. Two reasons for that is if you have cyclists going everywhere they want, whenever they want, then from our experience that will cause a negative impact on other users of the woods' (Manager 5)

A lack of opportunities for building and designing trails in ways which reflected the ethos of the youth sporting community and allowed participants independence from an organised club resulted in feelings of exclusion from decision making for a minority of participants in managed green spaces as demonstrated in the example below:

Researcher: 'So do you think you get much say in what happens here?' 'Um not as much as I'd like, just put it like that' (Participant 24: Age 18)

The desire for ownership and participation in wild build without permission presents a challenge for managers of green spaces who seek to encourage mountain biking and participation by young people. The next section of the findings demonstrates how managers are often required to adjust their strategies to acknowledge the practices and preferences of youth users alongside those of other user groups.

\section{Manager and User Negotiations}


Youth mountain bikers sought opportunities for autonomy and to contest normative management practices associated with supervised sites. Consequently, both managers and participants discussed tensions in their relationships with each other and conflicts over access to property. Conflicts between participants and managers or landowners usually occurred when wild build activities in secret spots were discovered and structures were removed or access prevented. The examples below show how wild build often breached health and safety regulations and managers were forced to remove anything that may cause injury.

'As soon as we know something is going on if we feel that it is a risk to the general public or to the people engaged in it we have to take some action as we have a duty of care and also criminal statute law' (Manager 2)

'When we first took over there were some people that would go off and build without permission but it's sort of made very clear now that it can potentially shut the site down so if anybody sees someone doing trail building which thankfully in the last three years nobody has' (Manager 3)

Lack of trail building experience was identified as a key problem from a management perspective. Young people had no training or expertise in trail building and managers identified modification to apparatus was often performed according to the trail builder's own skill level rather than enabling progression for a variety of riders. The account below demonstrates that for managed sites that have made a commitment to encouraging public access to facilities across a range of abilities this can cause significant problems. 
'The sort of people that want to get involved in building the trails want to build a lot of trail very quickly and then they can ride it the next day. So you know we obviously have standards that need to be upheld and to make sure the trail lasts a long time so that doesn't work well with that and also they will want to keep modifying the trail because they will be developing their cycling so neither of those things work well with the trails we are building about mass participation' Manager 9

For youth mountain bikers the actions of managers to curb their activities, such as demolishing jumps or prohibiting access, served as incentive to build more complex and ambitious projects.

'The first woods we rode in we started making loads more stuff in them and then that got trashed, that got chainsawed up, and then we moved further in the forest to a more hidden place, built there, built loads more stuff, we started building north shore ${ }^{2}$ and that all got chainsawed down as well' (Participant 22: Age 18)

'Every time we built something someone would come along and knock them down so we'd start again and build them twice the size' (Participant 31: Age 22)

In other examples, however, young people engaged in informal negotiations with landowners or managers to try and secure access to wild build. One respondent described how some jumps at his secret spot were knocked down because of safety fears and so he sought out the landowner in an attempt to gain permission to create something more permanent.

\footnotetext{
${ }^{2}$ North shore refers to raised wooden apparatus such as ramps and ladders.
} 
'We went to the local council found out the name of the person who owned the land and knocked on her door basically, and she was just like it keeps you off the street, keeps you out of trouble so go for it, well this was when we were about 14' (Participant 31: Age 22)

Two further participants described a process of trial and error which occurred between managers and themselves where respondents learnt what was and was not acceptable to build or alter in particular locations by what was left for them to use and what was removed.

'We've had our stuff cut down once. I think the problem is we cut down trees to make the northshore and I don't think they like that very much, and it's not that they don't mind us digging and stuff I think they prefer us doing that though. We don't cut down trees they're gonna harvest though we just cut down little ones' (Participant 11: Age 16)

'It's kind of like an unsaid agreement between the rangers and the builders, and as long as the builders don't build anything that you can't roll over then it's ok, anything else gets flattened, it's kind of a weird relationship that's not really legitimate but it sort of works for both sides' (Participant 40: Age 24)

Three participants described accessing spaces by setting up their own membership clubs that unlike others was operated and governed by young people themselves which removed some of the barriers to traditional club based participation. The respondent below 
described an agreement reached with landowners over a secret spot which used a participant run club to alleviate concerns about liability:

'The only reason they can keep them [secret spot] is if they set up a proper membership club, and there's loads of signs up there saying if you're not a member you can't ride, and stuff. I think they get a lot of kids saying they hurt themselves....so you can only go if you're a member or you've been invited' (Participant 28: Age 21)

For managers, engaging in dialogue with participants was considered a positive step and a dramatic shift from previous strategies of demolishing any wild build they uncovered. The respondent below described successful informal negotiations with young people that allowed the trail building to continue in a manner that suited the site, other users, and health and safety requirements.

'Initially our immediate reaction was to demolish everything and say we don't want this going on and we would rather this stopped and we would keep trashing it until you get the message and go away. That wasn't productive or helpful to anyone. We would now look at where the developments are going and whether it is appropriate for location and we have archaeology and SSSI's and occasional rare plants and local sensitivities. If you have just spent half a million pounds buying a lovely secluded property on the edge of the wood and someone is setting a two hundred member mountain biking site we have to be a little sensitive to that. So we consider whether it is appropriate area and whether we can manage it and then try and engage with the people that do it' (Manager 2) 
In a further example the respondent below sought a dedicated site for young people and the provision of earth moving equipment and finances to support their participation in jump building and mountain biking.

'We engaged with the local group and said listen where you are riding it is a sensitive protective soil type and we don't want you there but we have got this site over the other side and we will put some money in and bring a digger. There is nothing commercial about it it's just a load of jumps in the middle of the wood with no car park or sign or anything so we had to try and find out who the kids were that rode in there and try and encourage them to build jumps in a certain way' (Manager 5)

In these examples, managers recognised the value of the involvement of young people in wild build and its potential contribution to wider agendas in health and social wellbeing rather than viewing young people's activities as transgressive. The quote below demonstrates the sense of responsibility felt by one manager to provide opportunities for these activities wherever possible despite the challenges they may bring.

'Some of these sites have got local youngsters going out and actually working in the woodlands, building and riding their bikes is a huge success and it's a management thing it really is and making sure they are not doing it in unsuitable areas or whatever... while you have got a large population of people you will get young people who want to replicate what they see on DVDs and YouTube and ultimately it is up to us to make sure there is somewhere they can do it that is suitable' (Manager 9) 
Managers who recognised the potential for engaging young people embraced more informal approaches such as nurturing relationships with key individuals and adopting experimental or contextually specific approaches to encourage young people and continue their involvement alongside more conventional management approaches.

\section{Discussion}

Echoing the work of several youth theorists (White, 1993; Valentine, 2004; Owens, 2001), participants in this study discussed the policing and surveillance of leisure activities, in this case mountain biking. Similar to the work of Robinson (2009), these findings suggest young people prefer to congregate in outdoor spaces because they are less likely to encounter surveillance or restrictions to their activities. Green spaces were experienced as spaces on the margin (Shields, 1991), which were 'out of the town and tucked away' (Participant 24). In managed green spaces young people continue to encounter negativity in their use of them yet as others have also shown, young people in this study felt they were able to be absorbed by green spaces and could carry out much of their sport unobserved (cf. Bell et al., 2003; Leyshon, 2010).

As previous research on lifestyle sports has demonstrated, youth participation in mountain biking is characterised by a resistance to authority and opposition to normative ways of doing sport (Rinehart, 2007; King \& Church, 2015). This paper has shown that through participation in nature sports, peripheral, counter hegemonic activities such as wild build may also occur. Sites which provided opportunities for appropriation and creative wild build activities were more highly valued than those provided through formal, managed or commodified environments. (Borden, 2001; Downs, 2003; Rinehart \& Grenfall, 2002; Woolley et al., 2011). These activities can result in contestation between site users and this 
testing of boundaries is often poorly understood by resource managers (Bell et al. 2003). Managers in this research, however, showed a recognition of the value of these more complex activities to young people.

Youth mountain bikers and managers both felt that promoting a sense of community and ownership was crucial for successful management of mountain biking sites. Engaging local youth users in discussion facilitated a more productive approach to site management. Open communication between users and managers seems to remain a key method for ensuring the maximum use of the resource and for resolving conflict in management of sites for mountain biking. Managers of mountain biking locations, however, also viewed youth practices such as wild build and trail adaptation not simply as transgressive and anti-social but part of the negotiated process of managing green spaces where young people can be physically active through activities beyond the sport itself.

Strategies which required young people to engage with management through formal or organised club activities were least successful. Youth mountain bikers were resistant to joining official clubs which restricted managers abilities to monitor and control participation, and to involve young people in decision making at these sites. Instead, some managers adopted a more informal approach to negotiating with young people to maintain wild build spaces, limit young people's adaptation of managed formal trails and reach a compromise over the activities which occurred.

This research has demonstrated, that whilst not entirely problem free young people exercise significant agency in developing strategies to negotiate additional access to green spaces if required. In previous work, Gilchrist and Wheaton (2011) describe the actions of 
youth parkour participants to preserve and protect parkour spaces and in this study youth mountain bikers demonstrated the empowerment and resilience of youth lifestyle sport communities to overcome barriers to accessing leisure spaces. Youth mountain bikers were highly engaged in securing space for their sport and in seeking opportunities for participation. Rather than just rely on their hidden activities, some participants described attempts to negotiate with management staff and landowners, form their own clubs, or expose their activities to reduce the likelihood of losing the space entirely. Whilst many young mountain bikers experienced resistance to their activities they were often able to respond to these restrictions and create meaningful spaces for themselves. The emphasis on regular communication and negotiation between managers and young people as being at the core of managing conflict suggests the need to extend the approaches to managing recreational conflict beyond the more common responses identified by Watson et al. (2016) of zoning and education. The findings suggest that the successful management of these spaces requires not simply responding to different goals and values but also a recognition of the activities and views of young people that often include a desire for a sense of community and ownership linked to property and resources.

\section{Conclusion and implications}

There is limited research devoted to understanding the perceptions and experiences of young people who choose to access green spaces for leisure as it has been argued that the youth leisure experience has been largely understood through urbancentric approaches to research (Matthews, Taylor, Sherwood, Tucker \& Limb, 2000; McCormack, 2002; Leyshon, 2008; 2010; Valentine, Holloway, Knell \& Jayne, 2008). This study has sought to address 
this gap by exploring participation in a popular and growing lifestyle sport (i.e., mountain biking) by young people and their experiences of using green spaces.

Mountain biking is a lifestyle sport which offers an important means of being physically active in green spaces yet it is often portrayed in terms of its negative effects on other recreational users and ecology (Quinn \& Chernoff, 2010; White et al. 2006). It is underresearched in comparison to other lifestyle sports such as surfing, skateboarding, and parkour (Wheaton, 2010). This paper has therefore sought to explore how young people experience green spaces through mountain biking and the resultant strategies for management.

Young people who participate in lifestyle sports such as mountain biking have been identified as presenting a distinct set of challenges to managers of green spaces (King \& Church, 2015) This research shows that whilst they were presented with complex issues, managers recognised the benefits of both mountain biking and the peripheral wild build activities which accompany youth mountain biking and discussed various strategies for seeking to ensure that these activities could be legitimised within the realms of the green space sites. In addition, the study showed the will of young people to be engaged in decision making at mountain biking sites if they are involved in ways which allows them autonomy outside of a formal club system.

The findings have revealed how conflict is experienced by managers and young people and indicate that the dominant approaches to understanding conflicts in the literature based on social values and goal interference (Church, et al. 2007) need to be broadened to take account of the characteristics of resource settings and property relations which often strongly influence the nature of conflicts involving young people. Conflict is likely to 
continue to be an important issue as demand for outdoor recreation continues to grow (Rowe, 2012). Whilst previous research has identified education or zoning as effective strategies for conflict which is values based or related to goal interference (Watson et al. 2016), the conflicts between young people and managers considered in this paper were negotiated on a contextual basis and often informally between managers and active members of the local mountain biking community. Future research should focus on exploring the ways in which managers and groups of users informally and formally negotiate shared terms of use in green spaces.

As with the literature on conflicts in outdoor recreation generally, user perspectives tend to dominate in primary research and the views of managers are less well understood (Watson et al. 2016). This study has presented both user and manager perspectives on the use of green spaces by young people and in doing so has better understood the interactions between managers and user groups as a part of outdoor recreation research. This suggests future research should consider the role of research itself in connecting managers and user groups to discuss shared concerns.

Based on these conclusions, this study presents the following recommendations for managers seeking to encourage youth participation in mountain biking in green spaces:

- Seek to communicate with and engage the 'local' mountain biking community in site decision making.

- Avoid reliance on formal mountain biking clubs as a sole means of user group engagement as young people tend not to recognise these. 
- Provide opportunities for young people to learn trail building and design skills in site specific settings.

- Avoid formal sanctioning or zoning of trail building activity but instead seek to identify committed individuals who may act to represent the community and help managers to maintain contact and negotiate more effectively with youth groups.

By taking actions linked to these recommendations the organisations and managers that provide green spaces for mountain biking will be managing any conflicts that arise and recognising how young people wish to take part in lifestyle sports and hopefully encouraging physically, mentally and socially beneficial participation in nature sports. 


\section{References}

Beal, B., \& Weidman, L. (2003). Authenticity in the skateboarding world. In R.E. Rinehart \& S. Sydnor (Eds), To the extreme: alternative sports, inside and out, (pp. 337-52). Albany: State University of New York Press.

Bell, S., Ward Thompson, C., \& Travlou, P. (2003). Contested views of freedom and control: children, teenagers and urban fringe woodlands in central Scotland. Urban Forestry and Urban Greening, 2, 87-100. doi: 10.1078/1618-8667-00026.

Borden, I. (2001). Skateboarding, space and the city: architecture and the body. Oxford: Berg.

Brown, D. (2013). Young people, anti-social behaviour and public space: The role of community wardens in policing the 'ASBO generation'. Urban Studies, 50, 538-555. doi: $10.1177 / 0042098012468899$.

Brown, K.M. (2016). The role of belonging and affective economies in managing outdoor recreation: Mountain biking and the disengagement tipping point. Journal of Outdoor Recreation and Tourism.

Bryman, A. (2015). Social Research Methods. $4^{\text {th }}$ Ed. Oxford: Oxford University Press

Carothers, P., Vaske, J.J., \& Donnelly, M.P. (2001). Social values versus interpersonal conflict among hikers and mountain bikers. Leisure Sciences, 23, 47-61.

Cater, C.I. (2006). Playing with risk? Participant perceptions of risk and management implications in adventure tourism. Tourism Management, 27, 317-325.

Cessford, G. (2003). Perception and Reality of Conflict: Walkers and mountain bikes on the Queen Charlotte Track in New Zealand. Journal for Nature Conservation, 11, 310316.

Church, A., Gilchrist, P., \& Ravenscroft, N. (2007). Negotiating recreational access under asymmetrical power relations: The case of inland waterways in England. Society and Natural Resources, 20, 213-227.

Cooper, G. (2005). Disconnected children. ECOS, 26, 26-31.

Creswell J.W. (2003). Research Design, Qualitative, Quantitative and Mixed Methods. 2nd ed. Thousand Oaks, CA: Sage.

D’Antonio, A., Monz, C., Larson, N., \& Rohman, A. (2016). An application of recreation resource assessment techniques to inform management action in an urban-proximate natural area. Journal of Outdoor Recreation and Tourism, 14, 12-21 
DCMS. (2012). Creating a sporting habit for life: A new youth sport strategy. Department for Culture, Media and Sport. London: HMSO.

DH. (2010). Healthy Lives, Healthy People. Department of Health. London: HMSO.

Dougill, A.J., \& Stroh, M. (2001). Recreational users of Lake District bridleways: conflict or camaraderie? North West Geography, 1, 12-9.

Downs, B. (2003). Small bikes, big men. In R.E. Rinehart, \& S. Sydnor (Eds.), To the extreme: alternative sports, inside and out, (pp. 145-52). Albany: State University of New York Press.

Ewert, A. W., Dieser, R. B., \& Voight, A. (1999) Conflict and the recreational experience. In E. L. Jackson, \& T. L. Burton (Eds.), Leisure studies: Prospects for the twenty-first century, (pp. 335-345). State College, PA: Venture.

Flick, U. (2005) An Introduction To Qualitative Research. London: Sage.

Gardsjord, H.S., Tveit, M.S., \& Nordh, H. (2014). Promoting youth's physical activity through park design: Linking theory and practice in a public health perspective. Landscape Research, 39, 70-81. DOI: 10.1080/01426397.2013.793764

Gidlow, C. J. Ellis, N. J. (2011). Neighbourhood green space in deprived urban communities: issues and barriers to use. Local Environment, 16, 989-1002.

Gilchrist, P., \& Wheaton, B. (2011). Lifestyle sport, public policy and youth engagement: Examining the emergences of parkour. International Journal of Sport Policy, 3, 109131. doi: $10.1080 / 19406940.2010 .547866$.

Gill, T. 2014. The Benefits of Children's Engagement with Nature: A Systematic Literature Review. Children, Youth and Environments, 24, 10-34.

Goretzki, J., Esser, A., \& Claydon. R. (2008). Increasing participation in sport: Research Debrief. Report for Sport England. May $15^{\text {th }} 2008$.

Hallo, J.C., Manning, R.E. and Stokowski, P.A. (2009) 'Understanding and Managing the Off-Road Vehicle Experience: Indicators of Quality', Managing Leisure, 14, 195-209.

Hardiman, N. \& Burgin, S. (2013). Mountain biking: downhill for the environment or chance to up a gear? International Journal of Environmental Studies, 70, 976-986.

HHS. 2008. Physical activity guidelines for Americans. US Department of Health and Human Services, Office of Disease Prevention and Health Promotion. Washington: HHS. 
Hinds, J. (2011) Woodland adventure for marginalized adolescents: environmental attitudes, identity and competence. Applied Environmental Education \& Communication, 10, 228-237.

Hollenhorst, S.J., Schuett, M.A., Olson, D., \& Chavez, D. (1995). An examination of the characteristics, preferences, and attitudes of mountain bike users of the national forests. Journal of Park and Recreation Administration, 13, 41-51.

Holland, S., Renold, E., Ross, N., Hillman, A. (2010). Power, agency and participatory agendas: a critical exploration of young people's engagement in participative qualitative research. Childhood: A Global Journal of Child Research, 17, 360-375.

King, K. \& Church, A., 2013. We don't enjoy nature like that: youth identity and lifestyle in the countryside. Journal of Rural Studies, 31, 67-76.

King, K. \& Church, A., 2015. Questioning policy, youth participation and lifestyle sports. Leisure Studies, 34 (3), 282-302.

King, K. \& Church, A., 2017. Lifestyle sports delivery and sustainability: clubs, communities and user-managers. International Journal of Sport Policy, 9 (1), 107-119.

Leberman, S. \& Mason, P. (2000). Local Planning for Recreation and Tourism: A Case Study of Mountain Biking from New Zealand's Manawatu Region. Journal of Sustainable Tourism, 6, 97-115.

Lekies, K. S., Yost, G. \& Rode, J. (2015). Urban youth's experiences of nature: Implications for outdoor adventure recreation. Journal of Outdoor Recreation and Tourism, 9, 110.

Leyshon, M. (2008). The betweeness of being a rural youth: inclusive and exclusive lifestyles. Social and Cultural Geographies, 9, 1-26. doi: $10.1080 / 14649360701789535$.

Leyshon, M. (2010). The struggle to belong: Young people on the move in the countryside. Population Space and Place, 17, 304-325. doi: 10.1002/psp.580.

Lincoln, Y.S. \& Guba, E.G. (1985). Naturalistic inquiry. Sage: London.

Lloyd, K., Burden, J. \& Kiewa, J. (2008). Young girls and urban parks: Planning for transition through adolescence, Journal of Park and Recreation Administration, 26, pp. 21-38.

Mason, J. (2002). Qualitative Researching. $2^{\text {nd }}$ edition. Sage: London. 
Mason, P, Augustyn, M, Seakhoa-King, A. (2010). Exploratory Study in Tourism: Designing an Initial, Qualitative Phase of Sequenced, Mixed Methods Research. International Journal of Tourism Research, 12, 432-448. DOI: 10.1002/jtr.763

Matthews, H., Taylor, M., Sherwood, K., Tucker, F., \& Limb, M. (2000). Growing-up in the countryside: children and the rural idyll. Journal of Rural Studies, 16, 141-53.

Matthews, H., Limb, M., \& Taylor, M. (2000). The 'street as thirdspace'. In S.L. Holloway, \& G. Valentine, (Eds). Children's geographies: playing, living, learning. Routledge: London.

McCormack, J. (2002). Children's understandings of rurality: exploring the interrelationship between experience and understanding. Journal of Rural Studies, 18, 193-207.

Melo, R. \& Gomes, R. (2017). A Sociocultural Approach to Understanding the Development of Nature Sports. In R. Melo \& C. Sobry. Sport Tourism: New Challenges in a Globalized World. Cambridge Scholars Publishing: Cambridge. 47-76.

Milligan, C. \& Bingley, A.F. (2007). Restorative places or scary spaces? The impact of woodland on the mental well-being of young adults. Health and Place, 13, 799-811. doi: 10.1016/j.healthplace.2007.01.005.

Monrad, M. (2013). On a scale of one to five, who are you? Mixed methods in identity research. Acta Sociologica, 56, 347-360. doi: 10.1177/0001699313481368.

Németh, J. (2006). Conflict, Exclusion, Relocation: Skateboarding and Public Space. Journal of Urban Design, 11, 297-318. doi:10.1080/13574800600888343.

Nichols, G. (2007). Sport and crime reduction: the role of sports in tackling youth crime London: Routledge.

Owens, P.E. (2001). Recreation and restrictions: community skateboard parks in the United States. Urban Geography, 22, 782-97.

Owens, P.E. (2002). No teens allowed: the exclusion of adolescents from public spaces. Landscape Journal, 21, 156-63.

Pickering, C., \& Rossi, S. (2016). Mountain biking in peri-urban parks: Social factors influencing perceptions of conflicts in three popular National Parks in Australia. Journal of Outdoor Recreation and Tourism, 15, 71-81.

Quinn, M., \& Chernoff , G. (2010). Mountain Biking: A Review of the Ecological Effects. A Literature Review for Parks Canada. Quebec: Parks Canada. 
Rinehart, R.E. (2007). The performative avant-garde and action sports: Vedic philosophy in a postmodern world. In M. McNamee, (Ed). Philosophy, risk, and adventure sports, Abingdon: Routledge. 118-37.

Rinehart, R.E., \& Grenfall, C. (2002). BMX spaces: Children's grass roots' courses and corporate-sponsored tracks. Sociology of Sport Journal, 19, 302-14.

Roberts, K. (2006). Leisure in contemporary society. 2nd. CABI, Wallingford.

Robinson, C. (2009). Nightscapes and leisure spaces: an ethnographic study of young people's use of free space. Journal of Youth Studies, 12, 501-514. doi: $10.1080 / 13676260903081657$.

Rowe, N. (2012). Review of the research evidence on young people and sport: What does it tell us about their underlying attitudes and interest in sport and the ingredients for successful programme design. London: Sport England Research.

Ruff, A.R., \& Mellors, O. (1993). The mountain bike-the dream machine? Landscape Research, 18, 104-9

Sato, M., Jordan, J. S., \& Funk, D. C. (2014). The role of physically active leisure for enhancing quality of life. Leisure Sciences, 36, 293-313. doi:10/1080/01490400.2014.886912

Shields, R. 1991. Places on the margin: alternative geographies of modernity. London: Routledge.

Shildrick, T. Blackman, S. Macdonald, R. (2009). Young people, class and place. Journal of Youth Studies, 12, 457-465. doi: 10.1080/13676260903114136.

Sport England. (2014). The challenge of growing youth participation in Sport. Youth insights pack. August 2014. Henley Centre. Headlight Vision.

Sport England, \& Outdoor Industries Association. (2015). A study of demography, motivation, participation and provision in outdoor sport and recreation in England. Sport England, \& Outdoor Industries Association.

Sport England. (2016). Once a week participation in sport. Active People Survey 9. October 2014-September 2015. London: Sport England.

Taylor, M.F, \& Kahn, U. (2011). Skate-Park Builds, Teenaphobia and the Adolescent Need for Hang-Out Spaces: The Social Utility and Functionality of Urban Skate Parks. Journal of Urban Design, 489-510. doi:10.1080/13574809.2011.586142.

Thompson, A., Rehman, L., \& Humbert, M. (2005). Factors influencing the physically active leisures of children and youth: a qualitative study. Leisure Sciences, 27, 421-38. 
Tomlinson, A., Ravenscroft, N., Wheaton, B., \& Gilchrist, P. (2005). Lifestyle sports \& national sport policy: an agenda for research. Report to Sport England. London: Sport England.

Valentine, G. (2004). Public space and the culture of childhood. Aldershot: Ashgate.

Valentine, G., Holloway, S.L., Knell, C., \& Jayne, M. (2008). Drinking places: young people and cultures of alcohol consumption in rural areas. Journal of Rural Studies, 24, 28 40. doi:10.1016/j.jrurstud.2007.04.003

Van Bottenburg, M., \& Salome, L. (2010). The indoorisation of outdoor sports: an exploration of the rise of lifestyle sports in artificial settings, Leisure Studies, 29, 143 160. doi: 10.1080/02614360903261479.

Vaske, J. J., Donnelly, M. P., Wittmann, K. \& Laidlaw, S. (1995). Interpersonal versus social values conflict. Leisure Sciences, 17, 205-222.

Watson, A. E. Cordell, K. H., Manning, R. \& Martin, S. (2016). The evolution of wilderness social science and future research to protect experiences, resources and societal benefits. Journal of Forestry, 114. 329-338.

White, R. (1993). Youth and conflict over urban space. Children's Environments, 10, 85-93.

White, D., Troy Waskey, M., Brodehl, G.P., \& Foti, P.E. (2006). A comparative study of impacts of mountain bike trails in five common ecological regions of the southwestern U.S. Journal of Park and Recreation Administration, 24, 21-41.

Wheaton, B. (2010). Introducing the consumption and representation of lifestyle sports. Sport in Society, 13, 10571-81.

WHO. (2004). Global strategy on diet, physical activity and health. World Health Organization.

WHO. (2007). Steps to health: A European framework to promote physical activity for health. World Health Organization.

WHO. (2010). Global Recommendations on Physical activity for Health. WHO, Geneva. Retrieved from World Health Organisation: http://whqlibdoc.who.int/publications/2010/9789241599979_eng.pdf

Wood, B. E. (2012). Crafted within liminal spaces: Young people's everyday politics. Political Geography, 31, 337-346. doi:10.1016/j.polgeo.2012.05.003.

Woolley, H., Hazelwood, T. \& Simkins, I. (2011). Don't Skate Here: Exclusion of Skateboarders from Urban Civic Spaces in Three Northern Cities in England. Journal of Urban Design, 16, 471-487. doi: 10.1080/13574809.2011.585867. 
Zajc, P \& Berzelak, N. (2016). Riding styles and characteristics of rides among Slovenian mountain bikers and management challenges. Journal of Outdoor Recreation and Tourism, 11, 10-19. doi.org/10.1016/j.jort.2016.04.009. 